\title{
$\longrightarrow$

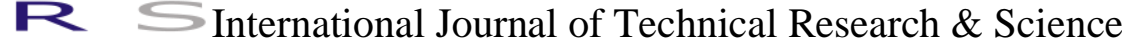 \\ REVIEW PAPER ON -ECOFRIENDLY \\ PRACTICE IN TEMPLE TO MAKE \\ SUSTAINABLE APPROACH TOWARD SOCIAL AND ENVIRONMENT
}

\author{
Shivangi, S Choudhary \\ E-Mail Id: shivangi.jagrawal@gmail.com \\ Faculty of Design, Vivekanand Global University, Jaipur, Rajasthan, India
}

\begin{abstract}
A place of worship is a specially designed structure or space where individuals or a group of people such as a congregation come to perform acts of devotion, veneration, or religious study. A building constructed or used for this purpose is sometimes called a house of worship.

To make green houses of worship is to have religious places engage in eco-friendly practices of worship, sustainably design and construct buildings, and most impact fully, to act as a centre of sustainable lifestyles and teachings within communities. The engagement on green issues is a journey that unfolds gradually.

Green practice enhances and protects biodiversity and ecosystems. Improve air and water quality. Reduce waste streams. Conserve and restore natural resources.

The paper discusses why we need to green worship place. The procedure would initially define the problem and the causes associated with it. Further, ways and methods of treating waste and extract valuable things and close loop approach would be discussed to find solutions for the problem. In the field of research waste management, sustainability and green concept is important issue. Sustainable and healthy future can be made by proper policies. Religious places also need some policies to convert in green worship place. Floral waste and its management from religious places has a close loop approach toward environment sustainability. Eco friendly practice in religious places makes huge difference in our country to minimize environment impact.
\end{abstract}

Keywords: floral waste, vermi compost, waste management, startup, CSR.

\section{INTRODUCTION}

Worship is a way of life in India, and people make various offerings to the gods, which mostly consist of flowers, leaves, fruits, coconuts, and clothing (Isha Yadav,2015).

Good and spiritual vibrations are attracted to temples, churches, gurudwaras, and mosques from their surroundings. People are accustomed to presenting flowers, garlands, coconuts, and milk to deities in temples as a sign of devotion and respect.

Every year, however, 80,000,000 tonnes of temple waste was poured into rivers, killing fish and other living creatures, wreaking havoc on the delicate environment, and resulting in massive water pollution. Pesticides and fertilizers also flow into the water, posing a serious danger to the citizens' lives.( ASK-EHS,2019)

Our temple offerings demonstrate that we give freely to our gods. Around 800 million tones of flowers, including roses and yellow marigolds, are distributed throughout the country's temples, mosques, and gurudwaras. Along with the roses, there are vermilion bags, plastic incense packets, and synthetic bangles. However, when these generous gifts become massive waste, it presents a difficult issue that is harmful to our community (Subhojit Goswami, 2018).The study would suggest an alternative solution to waste management, in which the waste will not be landfilled or burned, but rather recycled as a resource. It will shed light on how to reduce the amount of temple waste, resulting in increased revenue for temples. The use of holy waste would ultimately benefit society because people would be able to live in a cleaner and healthier world. The "green temple idea" may be useful in developing government waste management policies and promoting a sustainable development approach to temples. (Isha Yadav,2015).Flowers provided in temples go unused, and therefore end up as solid waste. This sacred garbage piles up at religious sites such as temples, mosques, and Gurudwaras. (Mishra,2013).Flowers are not disposed of in the traditional waste disposal system because they are an offering to God. As a result, it is dumped into rivers and streams, polluting already contaminated bodies of water. Varanasi is known as the "City of Temples" because it discards 3.5-4 tonnes of flower waste every day.(N. Mishra,Times of India,2017). Bengaluru's KR flower market alone produces approximately 15 tonnes of floral waste every day [R.Gowalla, ,2019].

This sacred waste can be properly handled and turned into a variety of value-added products. Techniques such as vermicomposting, composting, dye extraction, essential oil extraction, holi colour preparation, and bio-gas generation can all be used. (Kunal Adhikary, 2020)

Given the negative effect of excessive waste disposal on the environment, the current study aimed to better manage wastes by seeing them as a source of resources that can be turned into environmental sustainability by complete recycling. 


\section{T20 \\ 2. GREEN GUIDELINE FOR WORSHIP PLACE}

To build up green houses of worship is to have religious sites engage in eco-friendly practices of worship, sustainably design and construct buildings, and most impact fully, to act as a centre of sustainable lifestyles and teachings within communities.

\subsection{Waste Management}

Introduce waste separation into various colored containers, as well as recycling. Also work with local governments to request better waste disposal. The goal should be for all waste to be disposed of in an environmentally friendly manner, with proper waste separation and recycling. There are many measures for pollution and waste reduction, and facilitating reuse and recycling should be emphasized as well. Avoid generating waste as much as possible.

\subsection{Energy Efficiency}

All places of worship should aim for and achieve a reduction in energy use, as well as investigate and implement sensible and safe eco-alternatives.

Integrate renewable and low-carbon technologies to supply buildings' energy needs, once the design has maximized inbuilt and natural efficiencies. Reducing and greening energy consumption is crucial in the fight against global warming.

Increase access to secure, affordable and renewable energy. Connect buildings to low-emission district energy systems or green power grid (geothermal, biomass, wind, solar, etc.). Otherwise, install integrated photovoltaic (BIPV), solar thermal and micro-wind renewable energy systems in your house of worship. Extra capacity could even be provided or sold to communities. Switch to energy-saving light bulbs including LEDs, solar-powered LEDs, and compact fluorescent lights (CFLs). These emit the same amount of light though using a quarter of the energy and lasting more than seven times as long. Where possible, make use of natural lighting and ventilation.

\subsection{Awareness and Education}

Celebrate festivals around environmental themes and special days like Earth Day, World Environment Day, World Car Free Day, and so on. Organized activities can be cleaning up parks, car-free Sunday, tree-planting, spiritual outings, etc. All worship and gathering activities are low-noise, low-pollution, and low-emission. For instance, encourage people to walk or cycle to worship, save water. Collaborating with local organizations to raise environmental awareness or assist other communities in addressing environmental issues.

\subsection{Water Conservation}

Many sacred or ceremonial artifacts are thrown into rivers, like havan samagri and decoration materials such as fabric, polish, paint, cosmetic products, flowers, garlands, oily substances, polythene bags, and other plastic items become reason of water pollution. Need to conserve water body from water pollution and adopt water conservation measure like Hire a team to conduct an audit to determine how much water is used for various purposes such as drinking, bathing, and irrigation. Consider collecting rainwater to meet some of water requirements. Make use of bio-toilets.

\subsection{Green Landscape}

Green land scape around the temple helps to create carbon sink, it absorb corbondioxide. Increase the amount of green space in the worship place complex, using native species wherever possible. (ATREE,UNEP2020,ARC).

\section{WASTE GENERATION AND UTILIZATION OF TEMPLE WASTE}

Waste disposal, whether solid or semi-solid, is a major problem around the world. Mismanagement of temple waste, is one of the leading causes of environmental pollution. Floral waste is dumped directly into rivers, seas, and other bodies of water, wreaking havoc on the water quality as well as the living creatures that live in the waters and its environs. Pilgrims offer flowers to their gods since they are considered sacred beings. Every day, these flowers provided in temples go unnoticed and end up as solid waste. In India, large quantities of marigold flowers are sold in temples, resulting in a massive amount of waste. . In Varanasi alone, it is estimated that there are around 23000 temples. Since the city is situated on the Ganges River's bank, most flower wastes are dumped into the river, causing harm to the river's ecosystem, a foul odour, and serving as a breeding ground for a range of microbe-related diseases. However, this is a problem that affects the entire Indian subcontinent, not just this region. (Padmavathiamma., 2008; Wani 2013; Murthy, and Naidu, 2012). Everyday, these flowers are offered by devotees in temples and are left unused and therefore become waste. India is a country of festivals and many occasions are celebrated round the year that eventually leads to generation of solid waste. This proportion of waste is generally neglected and requires due consideration. Because of our religious beliefs, many of us avoid throwing flowers and other items that are used for prayers in the garbage, and instead put them in the plastic bags and throw them directly in the water bodies. Apart from this; flowers are also kept under the sacred trees and thus there is no suitable mode of disposal.

Typically, temple waste consists of organic waste such as flowers, leaves, coconut shells, vegetables, and other items that end up in bins or water bodies, causing contamination and hygiene issues. 


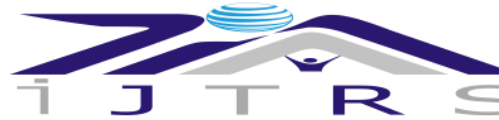

International Journal of Technical Research \& Science

For instance, Banaras, one of the holiest cities of the country, has no policy for disposal of the tonnes of waste that comes from its many temples. Each day waste material weighing 3.5-4 tonnes is left behind in the city of temples (Mishra, 2013).

As a result, the current paper has examined various methods for the utilisation and value addition of temple waste in various sectors that have been identified.

This floral waste can be utilized in different ways to produce valuable products and can thus help to save environment from pollution caused due to improper disposal of flower waste. Techniques like vermicomposting, composting, dyes extraction, extraction of essential oils, making of holi colours and bio-gas generation can be used. Moreover, this flower waste can also be used for making incense sticks besides using them for some art and craft techniques. Petals of different flowers can also be utilized for handmade papermaking by extracting the pulp or by mottling them into the readymade pulp.(Isha, 2015)

Degradation of floral waste is a very slow process as compared to kitchen waste degradation (Jadhav et al., 2013). Therefore, there is a need for proper and ecofriendly process of floral waste treatment. Management and utilization of flower waste has been carried out in some studies. One such example is the Kashi Vishwanath temple which draws maximum devotees all round the year, especially in the month of Shravan. It has its own system for disposal of hundreds of kilograms of waste resulting from offerings by devotees; the floral waste generated in the temple is converted into manure (Mishra, 2013).

Flowers like genda are used to make incense sticks, while roses are converted to rose water. Besides incense sticks and rosewater, the flowers can also be incorporated into herbal products such as herbal colours, natural dyes etc. (The Hindu, Jan., 2013).

Coconut is one of the extensively used offering in the temples and after removing its edible portion, the shell is generally thrown into the dustbins. These shells ultimately find their way into some water body or on some open areas/places thereby causing environmental problems. There is a vast scope of using the coconut shell as a potential or a replacement material in the construction industry. (Ahlawat and Kalurkar; 2014) undertook a study with the aim to produce a concrete by substituting granite with coconut shell. They made forty five cubes and their compressive strength and workability were assessed on 7, 14 and 28 days. The compressive strength of concrete was reported to be reduced as the percentage replacement increased. Concrete produced by $2.5 \%, 5 \%$, $7.5 \%, 10 \%$ replacement attained 28 days compressive strength of $19.71,19.53,19.08,18.91$ respectively. Thus it was reported that Coconut shell concrete can be used in reinforced concrete construction and its utilization is cost effective and eco friendly also.

\section{SCENARIO IN INDIA}

Over 1000 Hinduism temples are in a greening process under the guidance of various initiatives. temples are proactively becoming greener, generally switching to solar energy to reduce their carbon footprint. The Green Temple Initiative, organized by ARC, the Bhumi Project, and GPN, has even released a 'Green Temple Guide' in 2015. Stemming from Pujas to the temple landscape, from food to energy, from animal protection to waste management, this guide lists specific suggestions on the sustainable enhancement of traditional and modern practices of Hindu religions. Its members consist of Hindus, Sikhs and Baha'is. Solar energy is a common choice amongst the temples and ashrams under this initiative in India.

Bihar- The Management Committee of the Bodhgaya Temple in India collaborated with a dye manufacturer to transform 200 kilogrammes of floral waste into natural dyes. These dyes were soaked in authentic Khadi wear, available for sale in domestic and international markets.

Uttarakhand -Sivananda Ashram in Uttarakhand, Ambaji Temple in Gujarat and the Golden Temple in Amritsar (Sikh) have worked hard on waste management in the temples.

Tamil nadu- The MylaporeKapaleeshwarar Hindu Temple in India has transformed into a zero-plastic zone, with plastic bags banned not just inside the temple premises, but also in any of the surrounding shops. The items for offering, previously contained in polythene bags are now packed in reusable bamboo baskets.

Jharkhand- Temple of Baba BaidyanathThe temple authorities agreed to conquer this obstacle in 2016. Within the temple, the authorities implemented a waste management system.

The first step in this direction was to clean the temple twice a day rather than once a day. The second move was to deal with flower waste and reduce water waste. To combat this, temple officials made it obligatory for visitors to dispose of flowers in a single location within the temple and nowhere else. The flower waste is collected at the end of the day and sent to a composting facility. A water pouring pot inside the temple, dubbed 'Argha,' has been built to reduce water waste by allowing devotees to pour water through a single channel rather than spreading it across the temple.

Karnataka- Mahaganapathi Shakthi Kalyana Until November 2016, a heap of garbage containing both biodegradable and non-biodegradable waste was a popular sight in and around Karnataka's Shakthi KalyanaMahaganapathi, which receives around 500 devotees per day. Soon after, the temple administration agreed to take action and implemented a two-step plan to address the waste issue.

As a first move, the temple authorities made it illegal to distribute Prasad in plastic containers. It was also encouraged for devotees to carry their own containers. Furthermore, the temple began using dried leaves instead of plastic containers. 


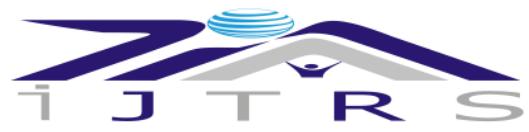

International Journal of Technical Research \& Science

The flower and kitchen waste were then composted as the second phase. Today, the temple has five leaf composters on site, which successfully turn all wet waste, such as fruits, kitchen waste, and flower waste, into manure, which is then used to beautify the temple grounds. The temple now sends zero wet waste to the local municipal corporation as a result of these two simple measures. The temple's non-biodegradable waste is often sent to nearby recycling facilities.

Amritsar- Golden Temple

The Golden Temple, one of India's most well-known devotional sites, has taken several measures to increase its cleanliness quotient, receiving over 1,20,000 devotees every day and five crore per year.Golden Temple is using compostable plastic bags made from potatoes and maize instead of regular plastic poly bags to reduce the use of single-use plastic products such as disposable plates, cups, and spoons and to turn to steel bowls for serving clean drinking water and steel plates for serving langar (food).

The Golden Temple, one of the Swachh Bharat Abhiyan's ten iconic locations, is also using solar energy to cook food in their community kitchen. The Shiromani Gurdwara Parbandhak Committee (SGPC) recently announced that it would turn to biogas, which is generated from vegetable waste, as the clean fuel of choice for its kitchen, which serves more than 60,000 people daily.

\section{START-UP -EXTRACT VALUABLE FROM FLORAL WASTE}

Indian start-up converts temple flower waste in to valuable things.a "flowercycling" startup has raised Rs 10+ crore $(\$ 120,000)$ to convert flower waste from the region's temples into valuable product. Phool, Help Us Green, Holy Waste are the start up based on floral waste generated from temple.

The Kanpur based startup company, named Phool, was founded by AnkitAgarwal in 2017 to keep the 8 tons of floral waste generated daily by the city's temples and mosques from being dumped into the Ganga river. The company has been converting the waste into incense sticks, compost, and biodegradable packaging.

According to a UN paper, Uttar Pradesh-based 'HelpUsGreen' has developed the world's first profitable solution to the monumental temple waste problem: 'flowercycling.' On a daily basis, the startup collects 8.4 tonnes of floral waste from temples in Uttar Pradesh. Via its 'flowercycling' technology, these sacred flowers are handcrafted into charcoal-free incense, organic vermicompost, and biodegradable packaging material.

Table-6.1 helpus green flower recycling data

\begin{tabular}{|l|l|}
\hline Recycled flower & 11,060 metric tonnes till date \\
\hline Collection per day from UP temple & 8.4 ton \\
\hline Empowering women & 1,260 \\
& \\
\hline
\end{tabular}

Holy Waste is Women run Telangana based startup. Holy Waste is a company created by two women that recycles floral waste from temples to make fragrant soaps and incense sticks. (Priyanka Richi,2019) Holy Waste now receives about $100 \mathrm{~kg}$ of floral waste three times a week from all over the city. What was once discarded in the GHMC's dumpyards has now been resurrected as fragrant soaps and incense sticks.

\section{CSR - PHILANTHROPHY}

The term corporate social responsibility (CSR) refers to practices and policies undertaken by corporations that are intended to have a positive influence on the world. Many companies have taken steps to improve the environmental sustainability of their operations, through measures such as installing renewable energy sources or purchasing carbon offsets.

CSR funding from ITC - Under the green temple initiative sponsored by CSR funding from ITC in association with Hindu religious \& charitable endowments (HR\&CE) department and Trichy Exnora, a biogas plant has been installed in Ranganathaswamy temple in Srirangam in March 2018. (Deepak karthik, the times of india).

CSR funding from Power Grid Corporation - Organic fertilizers through the newly installed solid waste management machine at Mansingh Pond near the temple complex by the Power Grid Corporation of India Limited under Corporate Social Responsibility (CSR) initiative. Offerings collected from all 22 temples in Deoghar by our volunteers are brought to MansinghChowk where a solid waste management plant has been installed. (Mukesh Ranjan, 2018, new Indian express).

CSR funding from Hindustan Zinc- Flowers offered daily at the Ajmer Sharif Dargah in Rajasthan are no longer going to waste. They are being recycled and used as compost for plants. Two recycling machines, installed by mining company Hindustan Zinc, churn out around $25 \mathrm{~kg}$ of compost each from $100 \mathrm{~kg}$ flowers.

CSR funding from state-owned Coal India Limited- As part of its corporate social responsibility, state-owned Coal India Limited has initiated two projects at Dakshineswar Kali Temple and Babadham Temple, in Deoghar, to produce organic fertiliser from the floral waste. These facilities are self-sustaining as NGOs manage the project and sell the fertilisers at the market. At the Kamakhya Devalaya, an in-situ waste segregating and processing system has been implemented. 


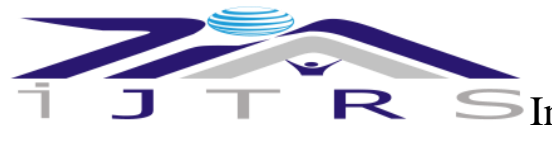

International Journal of Technical Research \& Science Table-7.1 CSR funding project

\begin{tabular}{|l|l|}
\hline $\begin{array}{l}\text { Angelique Foundation- Eight religious sites in Delhi } \\
\text { have installed machines to convert floral waste to } \\
\text { compost as part of an initiative by Angelique } \\
\begin{array}{l}\text { Foundation, the corporate social responsibility arm of a } \\
\text { Delhi-based company. Company name }\end{array}\end{array}$ & Project \\
\hline ITC & $\begin{array}{l}\text { Biogas plant has been installed in } \\
\text { Ranganathaswamy temple. }\end{array}$ \\
\hline Power Grid Corporation & $\begin{array}{l}\text { Solid waste management machine at Mansingh } \\
\text { Pond near the temple complex. }\end{array}$ \\
\hline Hindustan Zinc & $\begin{array}{l}\text { Two recycling machines, installed } \\
\text { at the Ajmer Sharif Dargah in Rajasthan }\end{array}$ \\
\hline Coal India Limited & $\begin{array}{l}\text { Two projects at Dakshineswar Kali Temple and } \\
\text { Babadham Temple, in Deoghar, to produce } \\
\text { organic fertilizer from the floral waste }\end{array}$ \\
\hline Angelique & $\begin{array}{l}\text { Eight religious sites in Delhi have installed } \\
\text { machines to convert floral waste to compost }\end{array}$ \\
\hline
\end{tabular}

\section{CONCLUSION}

In India worship is the integral part of life and flower offering is part of worship. After worship these flowers become waste and its disposal is posing ecological hazard because of slow degradation. Floral waste has potential to convert in wealth by using simple and economical technologies. If we do floral waste management it will generates employment and help to achieve financial sustainability by making diversified, valuable products from floral waste. Great things can achieve if religious committee, government, philanthropist, NGO work together and share best practice.

\section{REFRENCES}

[1] Gurav M. V, Pathade (2018), Production of Vermicompost from Temple Waste (Nirmalya): A Case Study, www.environmentaljournal.org, Universal Journal of Environmental Research and Technology,

[2] Green Temples Guide- An Environmental Guide for Hindu Temples and Ashrams (2015), www.arcworld.org

[3] IshaYadav, Shelja K. Juneja, and SunitaChauhan, 2015 Temple waste utilization and management: a review Kiran D A1 and Kavitha H2, Conference Paper (2020), Review on Flower Waste Management and its Conversion to Value Added Products to Conserve Environment, Five days Virtual International Conference on Sustainability and New Paradigms in Civil Engineering, Organised by DSCE, Bangalore

[4] KunalAdhikary, (2020), Management of Temple Floral Waste and Utilization of ValueAdded Floral Waste Product- A Review, International Journal of Advances in Engineering and Management (IJAEM),

[5] Mishra, (2013), Unholy mess: temple waste: a concern. Times of India. http://www.timesofindia.indiatimes.com

[6] M. S. Waghmode1• A. B. Gunjal2• N. N. Nawani3• N. N. Patil1, (2016) Management of Floral Waste by Conversion to Value-Adde Products and Their Other Applications, Springer Science+Business Media Dordrecht.

[7] Priyanka Tiwari1* Shelja K Juneja2 1,2, (2016), management of floral waste generated from temples of jaipur city through vermicomposting, the iis university, jaipur, rajasthan, india, international journal of environment.

[8] Sharmila Rani, Prateek Kumar Sharma, MenkaBhasin, (2020), Technology for Utilization of Floral Waste and Corresponding Products-A, ReviewInternational Journal of Scientific \& Engineering Research Volume.

[9] Singh, P.1,2*, Borthakur, A.3, Singh, R.4, Awasthi, Sh.1, Pal, D.B.5, Srivastava, P.6, Tiwary, D.1 and Mishra, P. K.5, , (2016),Utilization of temple floral waste for extraction of valuable products: A close loop approach towards environmental sustainability and waste management,

[10] T G Biju (2018), outlook https://www.outlookindia.com

[11] Wijayapala, S (2013): Utilisation of Sepalika (Nyctanthesarbortristis) flowers, a temple waste as a source for a potential coloring agent for textile substrates used in the textile industry. In: Proceedings of the International Forestry and Environment Symposium of the Department of Forestry and Environmental Science.

[12] A colourful solution to flower waste - UNEP, https://www.unenvironment.org/news-andstories/story/colourful-solution-flower-waste

[13] https://www.unenvironment.org/resources/publication/guidelines-green-houses-worship

[14] Recycling floral waste in https://www.ideassonline.org/public/pdf/IndiaRecyclingFlowers-ENG.pdf

[15] Recycling temple waste: Preserving the faith, ASK-EHS,2019, https://www.askehs.com/blog/environment/recycling-temple-waste-preserving/

DOI Number: https://doi.org/10.30780/IJTRS.V06.I06.002

pg. 16 